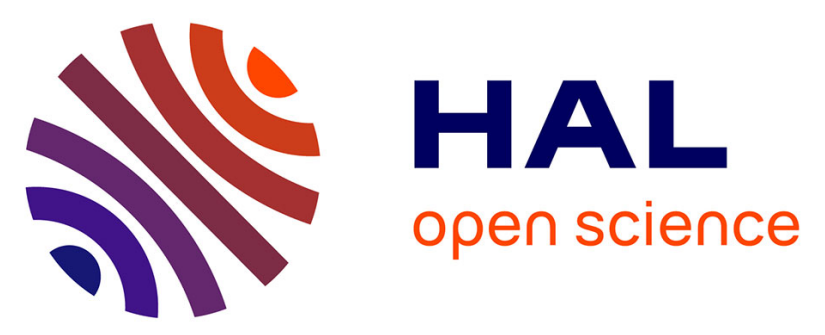

\title{
Efficient luminescence control in dithienylethene functionalized cyclen macrocyclic lanthanide complexes
}

Hassan Al Sabea, Nadège Hamon, Olivier Galangau, Lucie Norel, Olivier

Maury, François Riobé, Raphaël Tripier, Stéphane Rigaut

\section{- To cite this version:}

Hassan Al Sabea, Nadège Hamon, Olivier Galangau, Lucie Norel, Olivier Maury, et al.. Efficient luminescence control in dithienylethene functionalized cyclen macrocyclic lanthanide complexes. Inorganic Chemistry Frontiers, 2020, 7 (16), pp.2979-2989. 10.1039/D0QI00354A . hal-02903552

\section{HAL Id: hal-02903552 \\ https://hal.univ-brest.fr/hal-02903552}

Submitted on 27 Aug 2020

HAL is a multi-disciplinary open access archive for the deposit and dissemination of scientific research documents, whether they are published or not. The documents may come from teaching and research institutions in France or abroad, or from public or private research centers.
L'archive ouverte pluridisciplinaire HAL, est destinée au dépôt et à la diffusion de documents scientifiques de niveau recherche, publiés ou non, émanant des établissements d'enseignement et de recherche français ou étrangers, des laboratoires publics ou privés. 


\section{Efficient Luminescence Control in Dithienylethene Functionalized Cyclen Macrocyclic Lanthanide Complexes}

Hassan Al Sabea, $\uparrow ※$ Nadège Hamon, $+※$ Olivier Galangau, $\dagger$ Lucie Norel, $\uparrow *$ Olivier Maury, \# François Riobé, \# Raphael Tripiert** and Stéphane Rigautł**

† Univ Rennes, CNRS, ISCR (Institut des Sciences Chimiques de Rennes) - UMR 6226, F-

*To whom correspondence should be addressed. E-mail: 1ucie.norel@univ-rennes1.fr, raphael.tripier@univ-brest.fr, $\underline{\text { stephane.rigaut@univ-rennes1.fr }}$

RECEIVED DATE (to be automatically inserted after your manuscript is accepted if required according to the journal that you are submitting your paper to) 
4 Abstract. We report the synthesis of an original ligand scaffold based on a dimethyl-cyclen 5 platform Medo2pa with two dithienylethene units attached to each picolinate arms and the 6 corresponding yttrium(III), europium(III) and ytterbium(III) complexes. All three compounds

7 show reversible photochromism with high photo-conversions. Photoluminescence experiments

8 demonstrate that this design is versatile and adapted for both europium and ytterbium emission

9 switching when measured in frozen organic glasses at $77 \mathrm{~K}$. The OFF/ON luminescence ratio are excellent in the case of europium (4 to $8 \%$ ) and still quite good in the case of ytterbium (around $1113 \%)$.

Keywords: photochromism, ytterbium(III), europium(III), dithienylethene, cyclen, 14 azamacrocycles, luminescence, molecular switch.

\section{Introduction}

17 Responsive materials in which a key property can be modulated by an external stimulus in a controlled way are a great achievement in the field of molecular materials. ${ }^{1-2}$ Among them "alloptical" systems, that are triggered by light to change their optical (absorption, emission) properties, combine fast response, remote control and a low level of technical requirements for their implementation in real life applications. Applications could be as diverse as labels for cell imaging, ${ }^{3}$ super resolution imaging, ${ }^{4}$ anti-counterfeiting dyes, ${ }^{5-6}$ optical data-storage ${ }^{7}$ and many others.

24 In this context, several research groups have explored the photo-modulation of lanthanide-based 25 luminescent systems, ${ }^{5,16}$ mainly focusing on the association of photochromic compounds with 26 the red-emitting europium(III) ion. ${ }^{5,10-16}$ The ubiquitous diarylethene (DAE) photochromic units, ${ }^{17}$

27 on top of their excellent photo-physical properties, fatigue resistance and thermal stability of both open and closed isomers, is perfectly suited. Indeed, DAE scaffolds can be easily designed so that 
1 the closed isomers show strong absorptions around $610 \mathrm{~nm}$, matching the narrow emission lines of

2 europium(III) and then favoring emission quenching typically via an energy transfer. However,

3 according to this strategy, a complete quenching of europium luminescence in the closed form has

4 not been realized yet. The only total quenching of europium luminescence by a photochromic unit

5 reported to date consist of a tris(dipicolinate)europium core decorated with three $\mathrm{N}^{\wedge} \mathrm{C}$ chelate four 6 coordinate organoboron $\mathrm{T}$ type (reversible upon heating) photoswitches. ${ }^{15}$ Therefore, it is highly

7 desirable to achieve a complete optical control of ON/OFF switching of europium luminescence

8 with the P (thermally stable) photochromic DAE. Recently, some of us reported an example of

9 partial photo-modulation in a dithienylethene (DTE) appended dipicolinic amide europium

10 complex (Chart 1$),{ }^{18}$ and we hypothesize that a partial lability of the metal complex could be a

11 factor contributing to the moderate efficiency of the quenching in the closed form. At the same

12 time, surprisingly, this previous paper showed that DTE photochromic units could actually be more 13 versatile modulators of lanthanide luminescence than initially thought since ytterbium(III) NIR 14 emission could be sensitized by the $580 \mathrm{~nm}$ absorption of the closed isomer. Based on this, two 15 important goals remain to be achieved in this field: i) the improvement of the efficiency of europium(III) emission quenching by closed DTE system in order to reach real ON/OFF switching, and ii) the generalization and optimization of photo-modulation of ytterbium(III) ion by DTE units.

18 These two goals thus require a better understanding of the underlying photo-physical mechanisms and the exploration of new systems combining DTE and lanthanide ions.
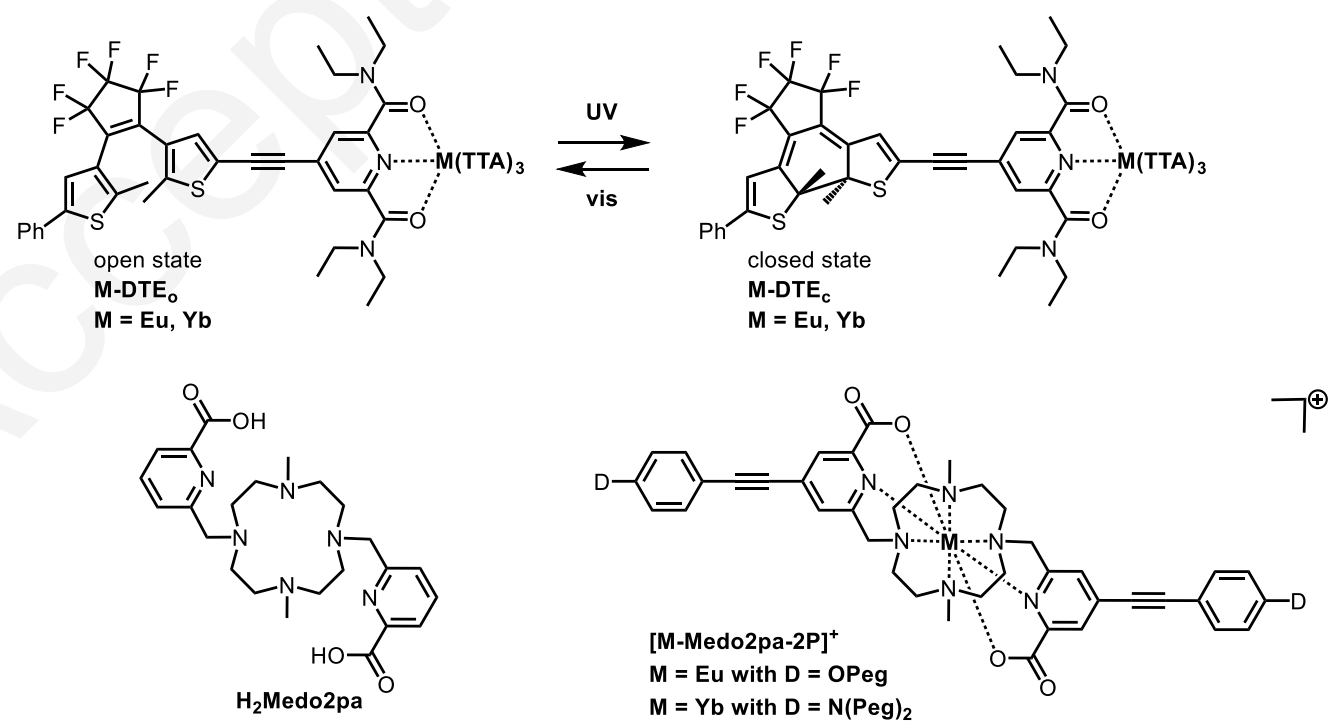
1 Chart 1. Previously studied systems. (top) M-DTE system shows versatile photo-modulation of

2 emission of both ytterbium(III) and europium(III) ions upon switching between the open and closed

3 state (TTA is 2-thenoyltrifluoroacetonate). ${ }^{18}$ (middle) Medo2pa provides water soluble and stable

4 lanthanide complexes and M-Medo2pa-2P chlorine salts enable cell imaging in the NIR range in

5 the case of the ytterbium(III) complex. ${ }^{19-20}$

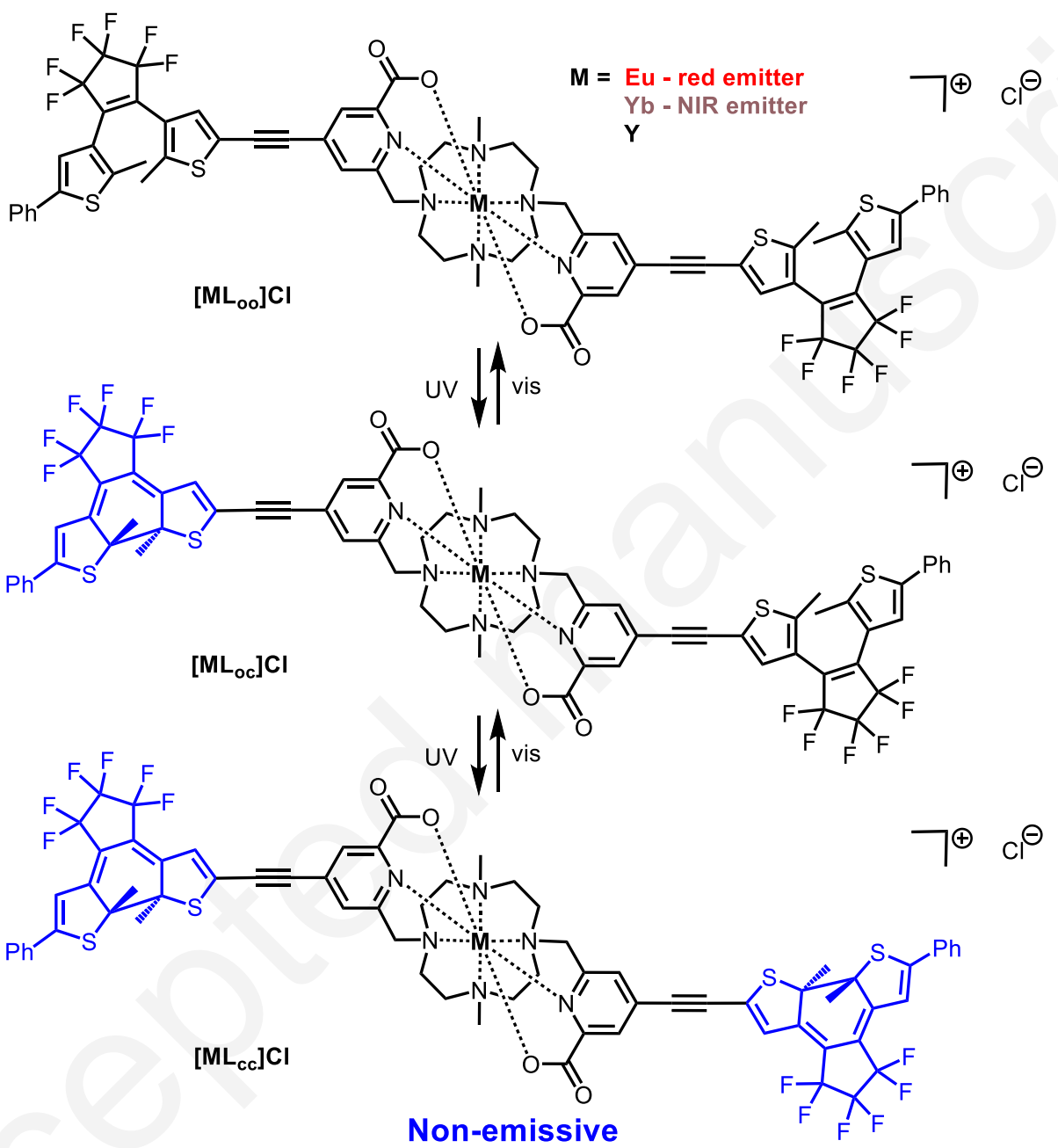

Chart 2. Targeted luminescence switches.

9 In parallel, macrocyclic lanthanide complexes have been widely studied as imaging bioprobes in general, ${ }^{3,} 21-22$ and as luminescent systems in particular. ${ }^{23-24}$ Among them, the cyclen based Medo2pa platform (Chart 1) has provided complexes of various lanthanide ions displaying high 12 stability constants, ${ }^{25}$ that are typically stable in water solutions. ${ }^{26}$ This cyclen platform $\mathrm{N}$ 13 functionalized by two picolinate pendants and two methyl groups, when modified with two photon 14 active conjugated antennas, provides bright luminescent europium(III) and ytterbium(III) 
complexes that are spontaneously internalized into live cells, ${ }^{19-20}$ the latter remaining highly

2 luminescent in biological media (Chart 1). ${ }^{20}$ Based on these convincing results, and complementary

3 to another strategy on based DTE modified acetyl acetonate ligands that we are developing in

4 parallel, ${ }^{27}$ we thought that the association of the Medo2pa platform with appropriate DTE units

5 could lead to "all optical" switches with improved stability and, therefore, better switching ratio

6 between the open and closed state, as well as to provide a new efficient ytterbium based switch in

7 the NIR range through the closed DTE unit sensitization. We therefore targeted the synthesis of a

8 new Medo2pa platform bearing two DTE units (on each picolinate arms) as shown in Chart 2. First

9 motivated by the ease of synthesis, the presence of two photochromic units within the same scaffold could also be anticipated as an advantage to improve i) quenching efficiency in the case of the europium(III) complex, and ii) sensitization through the closed DTE unit in the case of the ytterbium(III) complex. In this paper, we report on the synthesis of this new ligand and of the corresponding europium(III), ytterbium(III) and yttrium(III) complexes. We study in detail the photo-switching of these three metal complexes by absorption and $\left({ }^{1} \mathrm{H},{ }^{19} \mathrm{~F}\right) \mathrm{NMR}$ spectroscopies to illustrate that a reversible and complete isomerization occurs, the two DTE units behaving independently. Our strategy is proved effective in improving the quenching efficiency of europium luminescence as shown by a residual intensity of 4-8 \% of the initial one for the closed form as compared to the open one when measured at $77 \mathrm{~K}$. We also show that the ytterbium complex luminescence can be modulated at $77 \mathrm{~K}$ although it does not exhibit any sensitization through the closed DTE.

\section{Results and Discussion}

23 Complex synthesis. Synthesis of the target metal complexes $\left[\mathbf{M L o o}_{\mathbf{0}}\right] \mathbf{C l}(\mathrm{M}=\mathrm{Y}, \mathrm{Eu}, \mathrm{Yb})$ is described in Scheme 1. The DTE-photochromic-picolinate arm 1 was obtained by Sonogashira coupling from the alkyne terminated DTE and methyl 6-(hydroxymethyl)-4-iodopicolinate ${ }^{28}$ (see SI). Mesylation of the latter was performed under usual conditions and trans-dialkylation of the dimethyl-cyclen macrocycle with two equivalents of compound 2 in the presence of $\mathrm{K}_{2} \mathrm{CO}_{3}$ led to the desired di-ester 3 with an excellent yield of 95\%. Saponification of compound $\mathbf{3}$ in the presence of $\mathrm{KOH}$ in THF led to Loo as a potassium salt which was purified, thanks to a precipitation in an 
around 7. Washings with water and precipitations in $\mathrm{CH}_{2} \mathrm{Cl}_{2} /$ hexane gave the desired [MLoo] Cl with yields comprised between $61 \%$ and $90 \%$. These new compounds were fully characterized (see experimental section and SI). As characteristic features in its ${ }^{1} \mathrm{H}$ NMR spectrum, diamagnetic [YLoo]Cl exhibit shielded pyridine protons chemical shifts, similarly to other yttrium(III) dimethyl cyclen complexes, ${ }^{29}$ while the signals from the cyclen moiety become significantly broadened upon coordination (Figure S12). In the case of [EuLoo]Cl, additional paramagnetic shifts (pseudo contact shifts) are observed. Typically, the photochromic moiety shows small paramagnetic shifts, of around $-0.1 /-0.2 \mathrm{ppm}$ as compared with the yttrium(III) complex, while the pyridine protons are observed at $\delta=38.4$ and $25.8 \mathrm{ppm}$ and the cyclen protons give broad signals down to $-16 \mathrm{ppm}$ as expected (Figure S21). ${ }^{19}$ For $\left[\mathbf{Y b} \mathbf{L}_{\mathbf{o o}}\right] \mathbf{C l}$, in line with the greater magnetic anisotropy tensor of ytterbium(III) compared with europium(III), ${ }^{30}$ shifts of the same sign but of greater magnitude are observed, the pyridine protons being observed at $\delta=83.8$ and $55.5 \mathrm{ppm}$ and the cyclen ones down to $\delta=-40.5 \mathrm{ppm}$ (Figure S18). The paramagnetic shifts observed for the photochromic moiety are also larger with, for instance, the thiophene protons shielded to $\delta=6.97$ and $6.37 \mathrm{ppm}$ instead of $\delta$ $=7.47$ and 7.28 ppm in $[\mathbf{Y L o o}] \mathbf{C l}$.

Electronic absorption spectra and photochromism of $\mathbf{3}_{\text {oo }}$ and [MLoo]Cl. The absorption spectrum of $\mathbf{3}_{\mathbf{o o}}$ in DCM shows several intense bands in the UV range (Figure 1) that can be assigned to local $\pi-\pi^{*}$ transition of the picolyl unit $(275 \mathrm{~nm})$ overlapping with one of the DTE open form $(315 \mathrm{~nm})$. Upon irradiation at $330 \mathrm{~nm}$, a decrease of absorption is observed at $\lambda_{\max }=272$ $\mathrm{nm}$ while two new bands appear at $\lambda_{\max }=382$ and $607 \mathrm{~nm}$ (Figure 1). The initial spectrum can be recovered by $580 \mathrm{~nm}$ irradiation. This is in line with the usual photochromic behavior of DTE units $^{18}$ and consistent with the above mentioned assignment of the bands. Photo-cyclisation is evidenced by the characteristic lower energy band $\left(\lambda_{\max }=607 \mathrm{~nm}\right)$ ascribed to an intra-ligand (IL) transition centered on the closed DTE moiety. ${ }^{17}$ In this system with two DTE units, isomerization proceeds through the intermediate $\mathbf{3}_{\text {oc }}$ compound with one closed ring. However, at intermediate photo-conversions, no shifting of the lower energy transition was observed, suggesting that the two DTE units are electronically decoupled and behave independently in that case (Figure S24). ${ }^{31}$ The isomerization was also studied by ${ }^{1} \mathrm{H}$ NMR spectroscopy that proved that a high photoisomerization conversion (up to $94 \%$ of $\mathbf{3}$ cc and $6 \%$ of $\mathbf{3}$ cc) can be reached in the photo-stationary state (PSS) (Figure S29). Typically, the thienyl protons chemical shifts change from $\delta=7.25$ and 


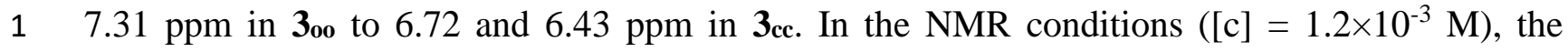

2 cycloreversion process is almost quantitative with the recovery of $\mathbf{3}_{\mathbf{0 o}}$ in $94 \%$ yield accompanied 3 by unknown species, probably coming from partial degradation upon prolonged exposure to light.

4 This behavior is in contrast to the more diluted UV-vis experiment that displays quantitative 5 recovering.
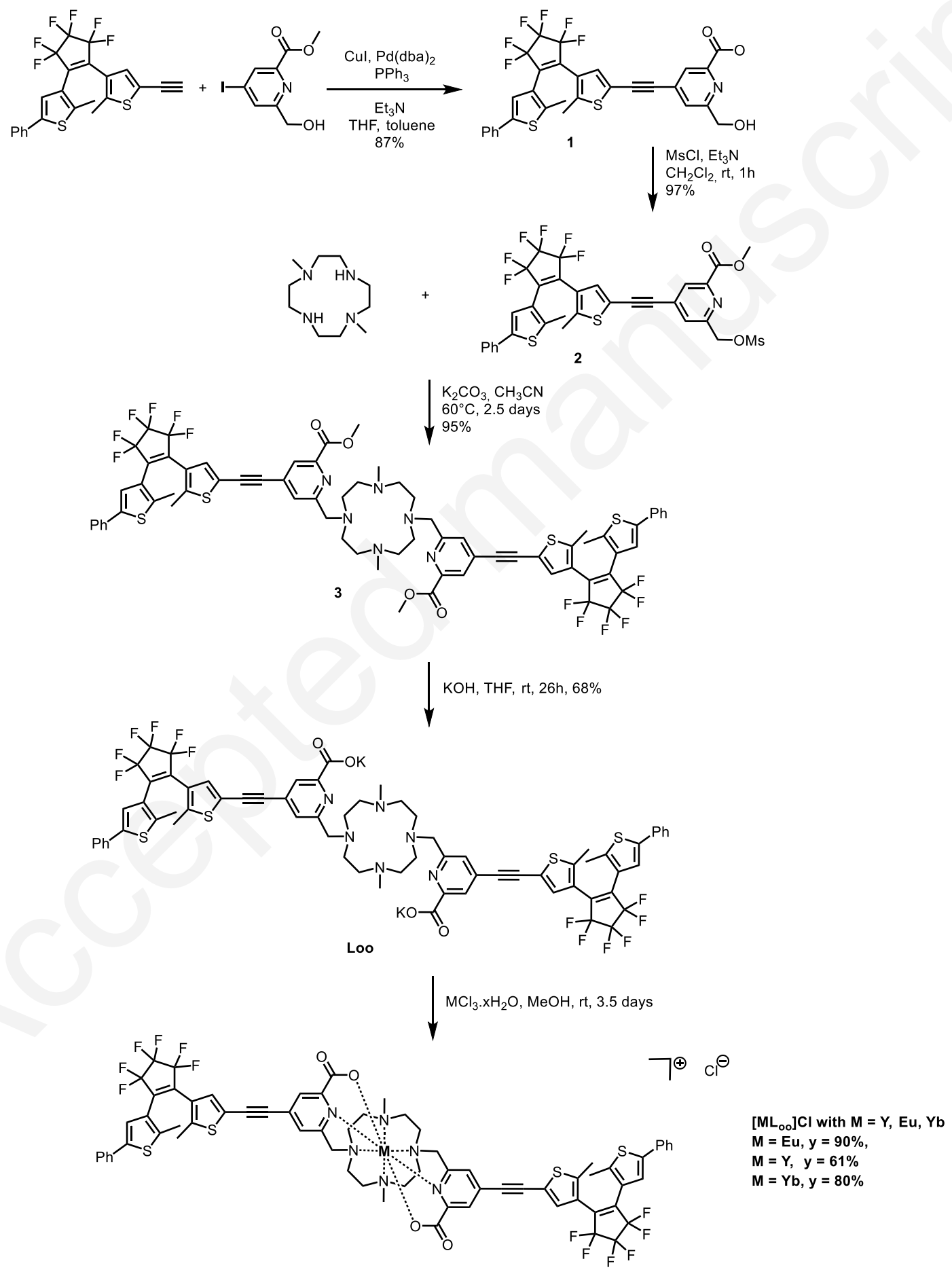
Scheme 2. Synthetic pathway yielding the target compounds.

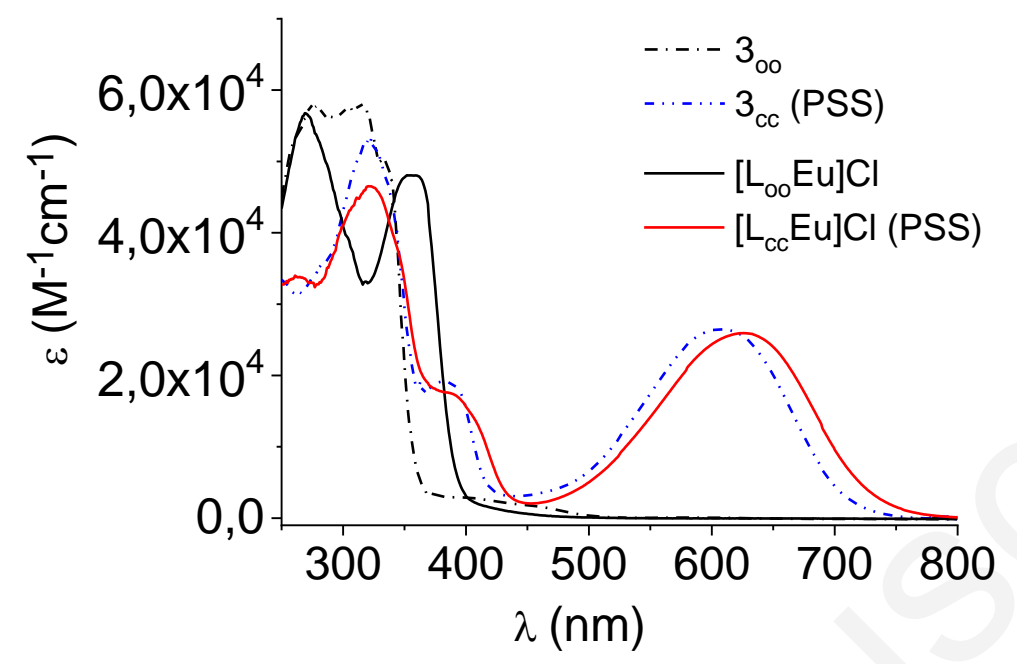

3 Figure 1. Electronic absorption spectra of $\mathbf{3}_{\mathbf{o}}$ and [ $\left.\mathbf{E u L} \mathbf{L}_{\mathbf{o o}}\right] \mathbf{C l}$ in $\mathrm{CH}_{2} \mathrm{Cl}_{2}$ solutions. Upon UV light irradiation

4 to PSS, the spectra of $\mathbf{3}_{\mathrm{cc}}$ and $\left[\mathbf{E} \mathbf{\mathbf { u L }} \mathbf{L}_{\mathrm{cc}}\right] \mathbf{C l}$ are obtained. The other compounds (Y, $\mathrm{Yb}$ ) show similar behavior

5 (see Table 1 and Figures S27 and S28). The initial spectra were recovered after bleaching at $580 \mathrm{~nm}$.

7 Once the cyclen group is coordinated, clean photochromic behavior, without photo-degradation 8 was observed as evidenced by the presence of isobestic points. The absorption spectra of the three 9 metal complexes are very similar with two main transitions at $\lambda_{\max }=269 \mathrm{~nm}$ and $350-360 \mathrm{~nm}$ and Figure 1 shows the representative behavior of the europium complex (the cases of $\mathrm{Y}$ and $\mathrm{Yb}$ complexes are depicted in Figures S27 and S28 respectively). Both bands are strongly modified upon UV irradiations and subsequent ring closure, and new transitions appear with $\lambda_{\max }$ values of 330 and $627 \mathrm{~nm}$. The lower energy transition is slightly red shifted upon coordination as compared with 3cc. Under visible light irradiation $\left(\lambda_{\max }=580 \mathrm{~nm}\right)$, the cycloreversion process is triggered as attested by the quantitative recovery of the initial spectra. Further ${ }^{1} \mathrm{H}$ NMR spectroscopy monitoring of the process unambiguously shows that the photochromic process upon UV irradiation is almost complete with the reaching of a photo-stationary state composed of ca. $95 \%$ of closed DTE units and a recovery of the initial spectra upon $580 \mathrm{~nm}$ irradiation, in contrast to the organic precursor. Details of the changes in the NMR spectra are highlighted in Figures 2 and S31. 


\begin{tabular}{|c|c|c|}
\hline compound & $\lambda_{\max }[\mathrm{nm}]$, corresponding energy $\left[\mathrm{cm}^{-1}\right]$ & $\varepsilon\left[\mathrm{M}^{-1} \cdot \mathrm{cm}^{-1}\right]$ \\
\hline 3 oo & 340,29400 & 40000 \\
\hline $3 \mathrm{cc}^{(\mathbf{a})}$ & $\begin{array}{l}382,26200 \\
607,16500\end{array}$ & $\begin{array}{l}19200 \\
28000\end{array}$ \\
\hline$\left[\mathrm{YLoo}_{\mathrm{C}} \mathrm{Cl}\right.$ & $\begin{array}{l}269,37200 \\
362,27600\end{array}$ & $\begin{array}{l}55600 \\
48300\end{array}$ \\
\hline$\left[Y_{\text {Lcc }}\right] \mathbf{C l}^{(\mathbf{b})}$ & $\begin{array}{l}330,30300 \\
627,15900\end{array}$ & $\begin{array}{l}42900 \\
27800\end{array}$ \\
\hline$\left[\mathrm{EuLoo}_{\mathrm{o}}\right] \mathrm{Cl}$ & $\begin{array}{l}269,37200 \\
352,28400 \\
\end{array}$ & $\begin{array}{l}53400 \\
45300\end{array}$ \\
\hline$[\mathbf{E u L c c}] \mathbf{C l}^{(\mathbf{b})}$ & $\begin{array}{l}339,29500 \\
627,16000\end{array}$ & $\begin{array}{l}39400 \\
24700 \\
\end{array}$ \\
\hline$[\mathbf{Y b L o o}] \mathrm{Cl}$ & $\begin{array}{l}269,37200 \\
347,28800\end{array}$ & $\begin{array}{l}57400 \\
45300\end{array}$ \\
\hline$[\mathbf{Y b L c c}] \mathbf{C l}^{(\mathbf{b})}$ & $\begin{array}{l}330,30300 \\
627,15900\end{array}$ & $\begin{array}{l}46000 \\
25900\end{array}$ \\
\hline
\end{tabular}

a) Photo-stationary state after $330 \mathrm{~nm}$ irradiation, b) photo-stationary state after $364 \mathrm{~nm}$ irradiation Table 1. Electronic absorption data for all compounds measured in DCM solutions.

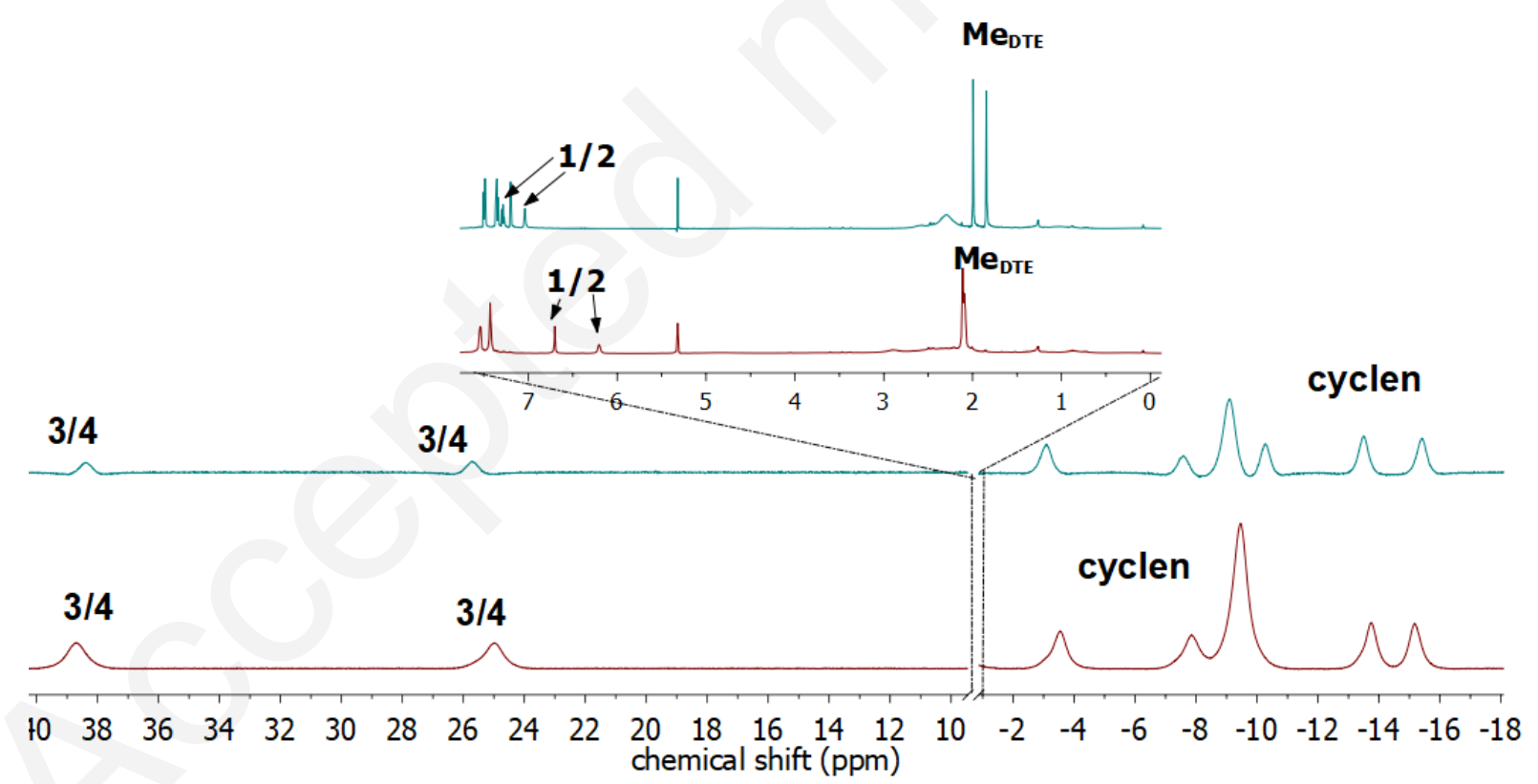

Figure 2. ${ }^{1} \mathrm{H} \mathrm{NMR}$ spectra $\left(500 \mathrm{MHz}, \mathrm{CD}_{2} \mathrm{Cl}_{2}, 298 \mathrm{~K}\right)$ measured during the course of [ $\left.\mathbf{L o o}_{\mathbf{o}} \mathbf{E u}\right] \mathbf{C l}$ 7 (blue line) isomerization to the PSS containing [ $\mathbf{L c c E u}] \mathbf{C l}$ and $[\mathbf{L o c} \mathbf{E u}] \mathbf{C l}$ with $95 \%$ of overall 8 closed DTE units (red line) upon $364 \mathrm{~nm}$ excitation in $\mathrm{CD}_{2} \mathrm{Cl}_{2}$.See Scheme 3 (experimental 9 section) for numbering. 
Photoluminescence of $\left[\mathrm{ML}_{\mathbf{o}}\right] \mathrm{Cl}$. We further studied the photoluminescence of all three metal complexes $(\mathrm{M}=\mathrm{Y}, \mathrm{Eu}, \mathrm{Yb})$. The yttrium complex serves as a reference to understand the photophysics of the ligand since no metal-based emission is expected for this compound. Thus, upon excitation at $\lambda_{\mathrm{ex}}=350 \mathrm{~nm}$ of [Y $\left.\mathbf{Y L}_{\mathbf{o o}}\right] \mathbf{C l}$ in an ethanol:methanol glass $(77 \mathrm{~K})$, a ligand-based fluorescence centered at $\lambda_{\mathrm{em}}=395 \mathrm{~nm}$ was observed (Figure S32) with the presence of additional peaks in its tail. A time-gated measurement performed with a $1 \mathrm{~ms}$ delay allows us to assign unambiguously these features to a simultaneous structured phosphorescence with maximum at $\lambda_{\mathrm{em}}$ $=517 \mathrm{~nm}$ and a corresponding lifetime of $14 \mathrm{~ms}$ at $77 \mathrm{~K}$ (Figure S33). This phosphorescence process corresponds to a ligand-centered triplet at around $19000 \mathrm{~cm}^{-1}$. Upon continuous irradiation at $350 \mathrm{~nm}$ and closing of the DTE units, both fluorescence and phosphorescence progressively disappeared, and at the PSS the closed yttrium(III) complex was almost non-emissive (Figure S32). Concerning the spectroscopy of the europium(III) complex, [EuLoo]Cl was studied at room temperature and at $77 \mathrm{~K}$. At room temperature, excitation at $350 \mathrm{~nm}$ induces both emission and competitive closing of the DTE units. The spectrum is actually dominated by an intense ligandcentered emission at $\lambda_{\mathrm{em}}=395 \mathrm{~nm}$ accompanied by a weak europium emission at $616 \mathrm{~nm}$ (Figure S34). In contrast, at $77 \mathrm{~K}$ in a methanol/ethanol organic glass, ligand centered emission is drastically decreased as compared with the sharp $\mathrm{f}-\mathrm{f}$ transitions. The difference in the response of the system with temperature could be ascribed to the occurrence of thermally activated back energy transfer that is hampered at $77 \mathrm{~K}$. We also observed a drastic slowing down of the closing reaction by this lowering of temperature and immobilization in an organic glass that allows one to measure the emission spectrum of pure [EuLoo] Cl with an excellent resolution. Therefore, the characteristic europium(III) emission profile assigned to the ${ }^{5} \mathrm{D}_{0} \rightarrow{ }^{7} \mathrm{~F}_{\mathrm{J}}(\mathrm{J}=0-4)$ transitions were detected at $\lambda_{\text {em }}$ $=580(\mathrm{~J}=0), 588,593,595(\mathrm{~J}=1), 610,613,622,627(\mathrm{~J}=2), 646,650,652,658,673(\mathrm{~J}=$ 3 ), and $694,704,711 \mathrm{~nm}(\mathrm{~J}=4)$ (Figure 4) and overall, the spectrum and particularly the crystal field splitting, is very similar to the one of a previously published europium(III) complexes with a similar Medo 2 pa ligand for which a $\mathrm{C}_{2}$ symmetry was calculated by DFT. ${ }^{19}$ The same measurement at $77 \mathrm{~K}$ was performed on [EuLcc] Cl (PSS state) and showed that an impressive quenching of europium luminescence occurs after closing of the DTE since only very weak emission (about $8 \%$ of the original intensity determined by integration of the open state more intense band $(J=2)$, see Figure 3) was detected. It is also possible to follow the emission quenching in the glass at $77 \mathrm{~K}$ upon successive scans, highlighting the progressive closing of the DTE during each luminescence 
1 measurement (Figure S35). An attempt to reach the PSS was performed upon irradiation of the 2 glass during $1000 \mathrm{~s}$. A $90 \%$ quenching was achieved after only $40 \mathrm{~s}$ but the complete closing was 3 not reached at the end of the experiment where less than $4 \%$ of the initial emission was still 4 observed. A perfect reproducibility of the behavior was observed after several re-opening were 5 performed with white light irradiation (Figure 4).

6

17 Figure 3. Emission spectra $\left(\lambda_{e x}=350 \mathrm{~nm}\right)$ of $\left[\mathbf{L}_{\mathbf{o o}} \mathbf{E u}\right] \mathbf{C l}$ (black line) and [LccEu]Cl. (red line) in 18 ethanol: methanol (4:1) organic glass at $77 \mathrm{~K}$.

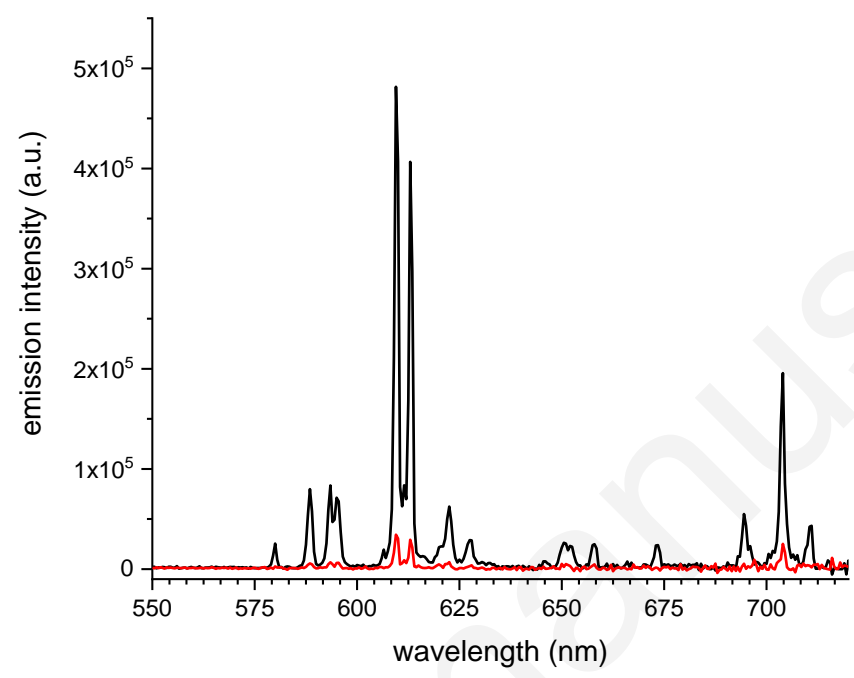

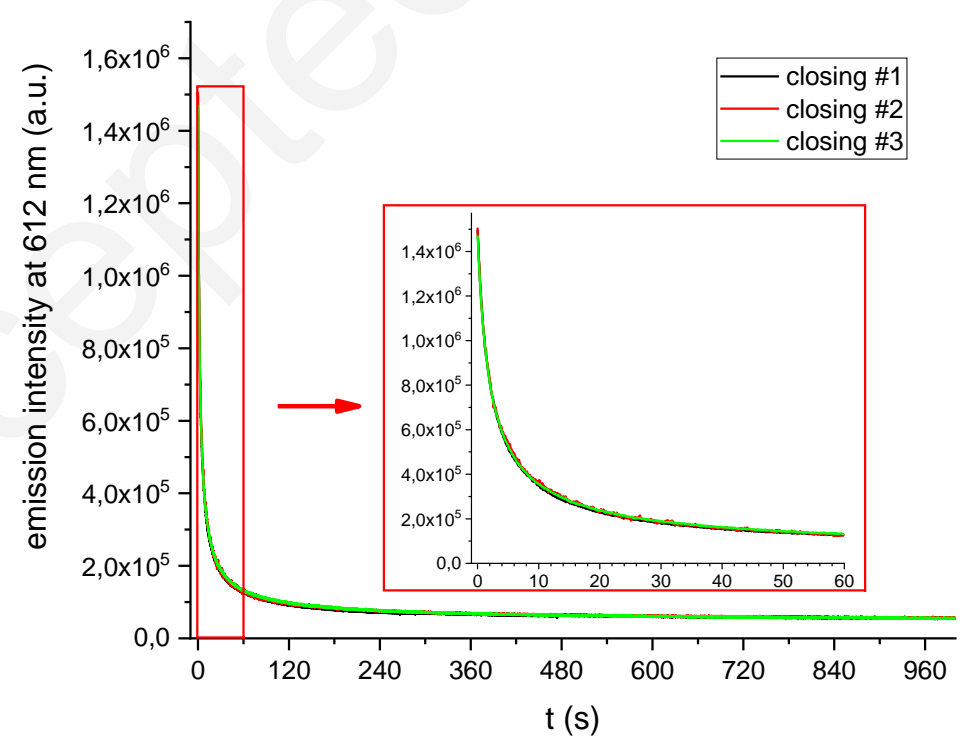


1 Figure 4. Emission at $612 \mathrm{~nm}\left(\lambda_{\mathrm{ex}}=350 \mathrm{~nm}\right)$ of $[\mathbf{L o o} \mathbf{E u}] \mathbf{C l}$ while isomerizing to [ $\left.\mathbf{L c c E u}\right] \mathbf{C l}$. in 2 ethanol : methanol (4:1) organic glass at 77K. Two other successive measurements are performed 3 after discoloration with white light (at RT).

5 Concerning [YbLoo]Cl, no ytterbium emission was detected upon $350 \mathrm{~nm}$ excitation at room 6 temperature. In contrast, in an ethanol/methanol organic glass at $77 \mathrm{~K}$, the typical emission of 7 ytterbium(III) was detected in the NIR. In order to avoid distortion of the signal due to concomitant 8 closing, the emission was detected with a CCD camera. First, a resolved spectrum can be obtained, 9 clearly showing the different lines expected for the ${ }^{2} \mathrm{~F}_{5 / 2} \rightarrow{ }^{2} \mathrm{~F}_{7 / 2}$ transition and again very similar to previously reported ytterbium(III) complexes with $C_{2}$ symmetry, ${ }^{20}$ with the main crystal field 11 splitting lines at 971, 996, 1025 and $1040 \mathrm{~nm}$ (Figure 5). In order to follow the effect of photo12 isomerization on ytterbium emission, fast-acquired successive spectra were obtained, clearly 13 showing a 10 fold quenching of luminescence due to the closing reaction (Figure S36). Note that 14 the quenching ratio is not rendered by Figure 5 because the initial intensity actually corresponds to a system already undergoing a significant amount of closing. Rather, the ratio between the initial and final states can be obtained from integration of the fast acquired data (Figure 6), giving a $13 \%$ ratio. Finally, we have addressed the possibility of sensitization by excitation at $600 \mathrm{~nm}$, and unlike

18 Yb-DTE (Scheme 1) no ytterbium emission was detected in such case. ${ }^{18}$ For both europium and 19 ytterbium complexes, it is unclear whether the remaining emission after closing arises from the 20 closed species or whether a PSS composition different from the one in DCM solutions at room 21 temperature (95\% of closed units, no remaining oo isomer) is reached due to immobilization in a 22 frozen organic glass. 


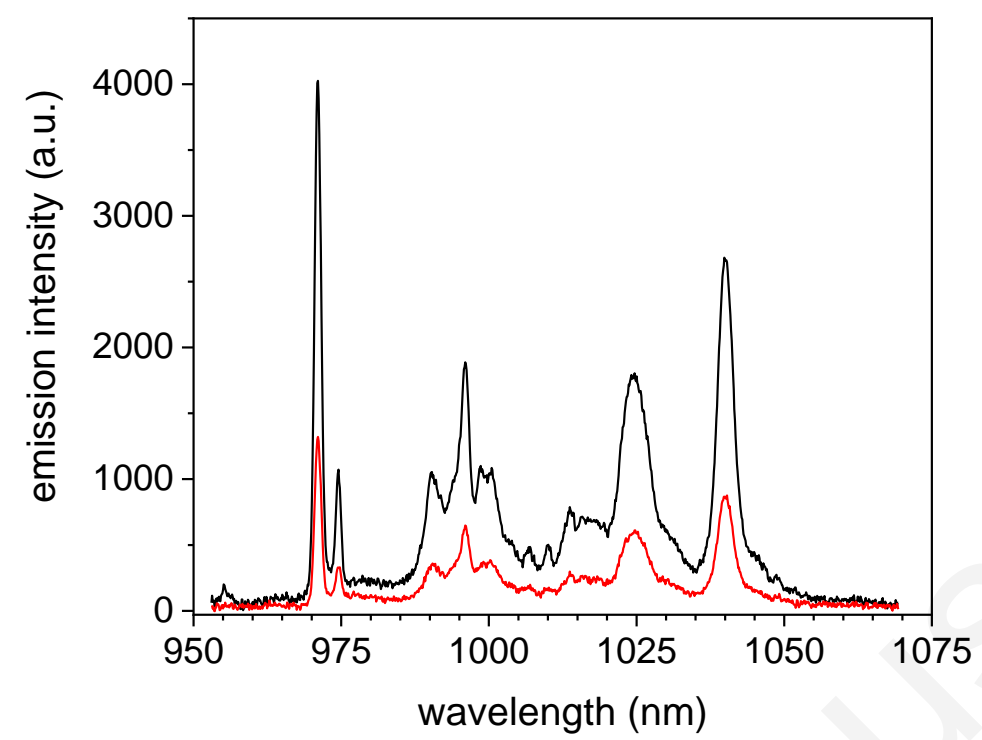

2 Figure 5. Emission spectra $\left(\lambda_{\mathrm{ex}}=350 \mathrm{~nm}\right)$ of [ $\left.\mathbf{L o o}_{\mathbf{o r}} \mathbf{Y b}\right] \mathbf{C l}$ (black line) and [ $\mathbf{L c c} \mathbf{Y b} \mathbf{b} \mathbf{C l}$. (red line) in 3 ethanol: methanol (4:1) organic glass at $77 \mathrm{~K}$.

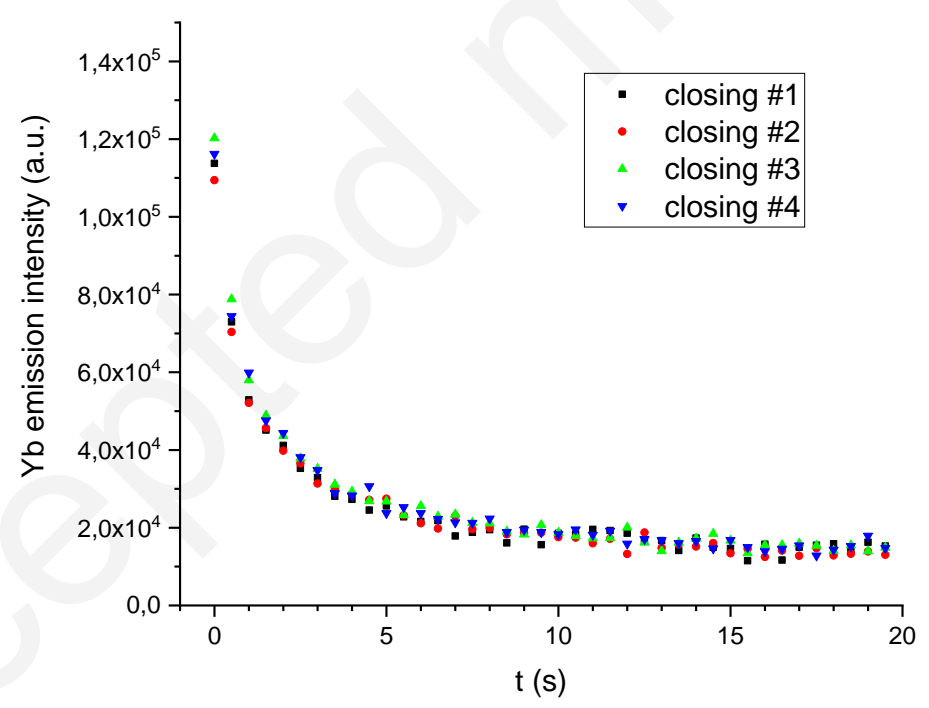

4

$5 \quad$ Figure 6. Emission (integrated intensity from Figure S36) at $1000 \mathrm{~nm}\left(\lambda_{\mathrm{ex}}=350 \mathrm{~nm}\right)$ of $[\mathbf{L o o} \mathbf{Y b}] \mathbf{C l}$ 6 while isomerizing to $[\mathbf{L} \mathbf{c c} \mathbf{Y b}] \mathbf{C l}$. in ethanol : methanol (4:1) organic glass at $77 \mathrm{~K}$. Two other 7 successive measurements are performed after discoloration with white light (at RT). 


\begin{tabular}{|c|c|c|c|}
\hline Compounds & Conditions & $\begin{array}{l}\text { Ratio of Europium based } \\
\text { luminescence } \\
\text { (OFF state/ON state) }\end{array}$ & reference \\
\hline Eu-DTE $_{0}$ & RT, DCM & $60 \%$ & 18 \\
\hline DAE-tpy-Eu(TTA $)_{3}$ & $\mathrm{RT}, \mathrm{CHCl}_{3}$ & $20 \%$ & 14 \\
\hline $\begin{array}{l}\text { Host guest complex of } \\
\text { (terpyridinyldibenzo-24-crown- } \\
\text { 8)Eu(TTA) })_{3} \text { and DAE }\end{array}$ & $\begin{array}{lr}\mathrm{RT}, \quad 1: 1 \\
\mathrm{CH}_{3} \mathrm{CN} / \mathrm{CHCl}_{3}\end{array}$ & $20 \%$ & 16 \\
\hline \multirow{2}{*}{$\begin{array}{l}\text { Triangle terthiazole } \mathrm{Eu}(\mathrm{hfac})_{3} \\
\text { complex }\end{array}$} & RT, dioxane & $36 \%$ & $10-11$ \\
\hline & $\begin{array}{l}80 \quad \mathrm{~K}, \\
\text { EtOH/MeOH } \\
\text { glass matrix }\end{array}$ & $\mathrm{ND}^{\mathrm{a}}$ & $10-11$ \\
\hline $\begin{array}{l}\text { Sulfone-DTE } \quad \mathrm{Eu}(\mathrm{hfac})_{3} \\
\text { complex }\end{array}$ & $\begin{array}{l}\mathrm{RT}, \\
\text { ethylacetate }\end{array}$ & $60 \%$ & 32 \\
\hline $\begin{array}{l}\text { (5,6-dithienyl-1,10- } \\
\text { phenanthroline }) \mathrm{Eu}(\mathrm{acac})_{3}\end{array}$ & RT, ethanol & $30 \%$ & 5 \\
\hline \multirow{2}{*}{$\begin{array}{l}\text { (DTE- } \beta- \\
\text { diketonate })_{3} E u(\text { phenanthroline })\end{array}$} & RT, DCM & $1 \%$ & \multirow[t]{2}{*}{33} \\
\hline & RT, Film & $5 \%$ & \\
\hline$\left[\mathrm{L}_{00} \mathrm{Eu}\right] \mathrm{Cl}$ & $\begin{array}{l}77 \mathrm{~K} \text {, ethanol } \\
: \quad \text { methanol } \\
(4: 1)\end{array}$ & $4-8 \%$ & This work \\
\hline $\begin{array}{l}\text { (DTE- } \beta \text {-diketonate })_{3} \mathrm{Yb}(\mathrm{bpy}- \\
\text { Ru-alkynyl) }\end{array}$ & RT, DCM & $1.4 \%$ & 27 \\
\hline $\begin{array}{l}\text { (DTE- } \beta- \\
\text { diketonate) })_{3} \mathrm{Yb}(\text { phenanthroline })\end{array}$ & \begin{tabular}{|l|} 
RT, DCM \\
RT, film
\end{tabular} & $2 \%$ & 33 \\
\hline$\left[\mathrm{L}_{00} \mathrm{Yb}\right] \mathrm{Cl}$ & $\begin{array}{l}77 \mathrm{~K} \text {, ethanol } \\
: \quad \text { methanol } \\
(4: 1)\end{array}$ & $13 \%$ & This work \\
\hline
\end{tabular}

1 Table 2. Previously studied complexes showing reversible luminescence switching with DAE

2 photochromic units compared with this work. TTA $=2$-thenoyltrifluoroacetonate, hfac $=1,1,1,5,5,5$ -

3 hexafluoroacetylacetonate, aca $=$ acetylacetonate, tpy $=$ terpyridine. 
1 a. emission QY are $10 \%$ for the open state and $7.6 \%$ for the closed one and no photoreaction 2 occurs.

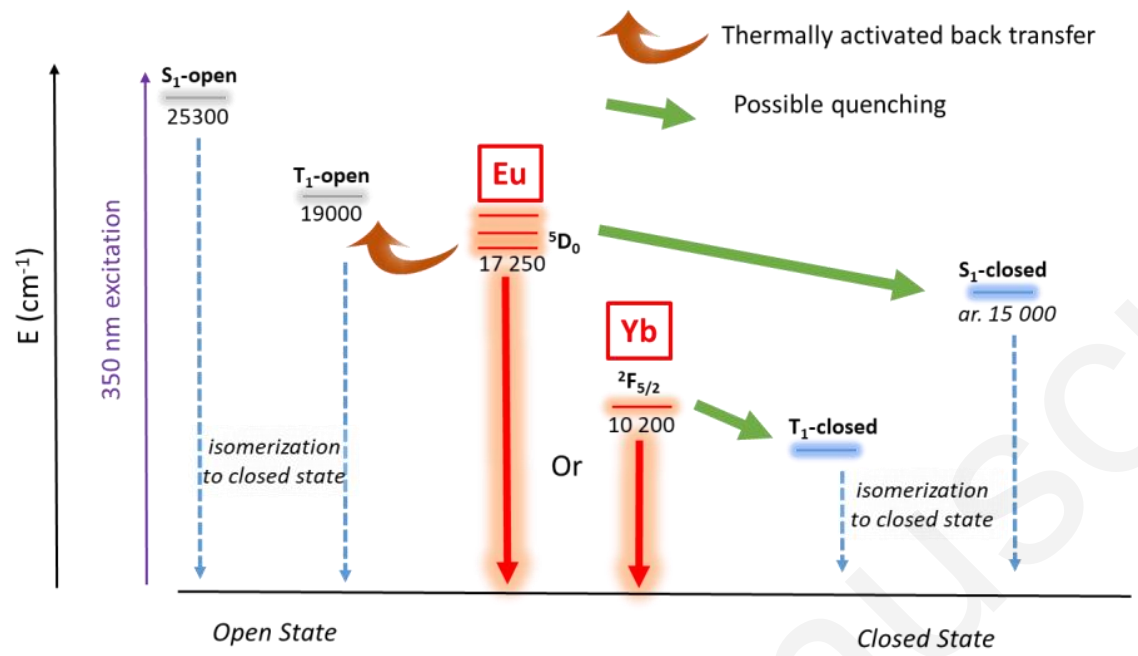

4

$5 \quad$ Figure 7. Tentative Jablonski diagram showing the different photophysical processes.

7 Discussion. Altogether, and in light with the objectives mentioned in the introduction, the results 8 of the photoluminescence experiments deserve a few comments. First, temperature/medium 9 dependence of the response is very spectacular for both systems and in both cases, no lanthanide based emission can be detected at room temperature, in contrast to previously published systems gathered in Table 2. In the case of europium, this is probably because of thermally activated backtransfer, hence causing ligand-centered emission as suggested by the presence of the open form ligand triplet state at $19000 \mathrm{~cm}^{-1}$ (see Figure 7). In the case of ytterbium, it is more likely that luminescence is inherently weak due to efficient non-radiative processes and therefore difficult to detect without causing the closing of the DTE. At $77 \mathrm{~K}$ in an organic glass, the non-radiative processes are drastically slowed down as well as the closing reaction and both factors favor the observation of ytterbium emission. Second, when measured in appropriate conditions, the contrast between the responses of the two states for our europium complex is much higher than in previous photoswitchable systems based on europium and diarylethene combinations (Table 2) and only one example relying on $\mathrm{N}^{\wedge} \mathrm{C}$ chelate four coordinate organoboron photoswitches of $\mathrm{T}$ type previously showed better quenching ratio. ${ }^{15}$ Provided that back transfer and non-radiative processes are reduced by further chemical engineering, our design with a macrocycle bearing two DTE units could lead to very efficient RT europium luminescence switches, more suitable for applications. ${ }^{33}$ 
1 Nonetheless, this design leads to the third example of efficient ytterbium luminescence photo-

2 control reported so far. In that case, the mechanism for emission quenching does not rely on spectral

3 overlap between the closed DTE and the lanthanide emission lines and we are currently

4 investigating the possibility of a low lying triplet state quenching the emission in the closed state

5 (Figure 7). We also postulate that the position of this state is not favorable to sensitization of

6 ytterbium emission through the visible transition of the closed DTE unit unlike in Yb-DTEc. This

7 leaves room for improvement of ligand design in order to obtain optimized positioning of this state

8 depending on the targeted behavior ie UV sensitization with quenching by a low lying state or

9 controllable visible light sensitization.

Conclusion.

12 With this work, we report the synthesis of an original ligand scaffold with two DTE units attached to a cyclen based macrocycle designed for luminescence switching and the corresponding complexes of yttrium(III), europium(III) and ytterbium(III). All three metal complexes show reversible photochromism with high photo-conversions. Our design proved to be versatile and adapted for both europium and ytterbium emission switching, when measured in frozen organic glasses. The $\mathrm{OFF} / \mathrm{ON}$ luminescence ratio are excellent in the case of europium compared to all previously published compounds and still quite good in the case of ytterbium, that represents the second example of such behavior. More important, our study, combined with on-going in depth photo-physical studies, will contribute to the understanding of important factors for the design of further improved molecular switches with custom switching, excitation and emission wavelengths.

Acknowledgments. We thank the Université de Rennes 1, the CNRS, the MESR, for support. H. A. S. thanks GDR MCM-2 for funding a short stay at the Laboratoire de Chimie in Lyon.

Supporting Information Available: Synthetic procedures for compounds 1 and 2. NMR spectra and HRMS of all metal complexes. Photo-isomerization studies (absorption and NMR spectroscopy). Additional photoluminescence details.

\section{Experimental Section.}


2 General comments: Reagents were purchased from ACROS Organics and from ALDRICH

3 Chemical Co. Cyclen was purchased from Chematech (Dijon, France). Dimethyl-Cyclen was 4 synthesized as previously described. ${ }^{26}$ The solvents were freshly distilled prior to use and according 5 to the standard methods. NMR spectra $\left({ }^{1} \mathrm{H},{ }^{19} \mathrm{~F}\right.$ and $\left.{ }^{13} \mathrm{C}\right)$ were recorded at the core facilities of the 6 University of Brest, with Bruker Advanced 500 (500 MHz) or Bruker AMX-3 $300(300 \mathrm{MHz})$ 7 spectrometers or at the Centre Régional de Mesures Physiques de l'Ouest on a Bruker Avance III 8 HD 500 (500 MHz). The HR-MS analyses were performed at the Institute of Analytic and Organic 9 Chemistry, ICOA in Orléans. Elemental Analysis were performed at Centre Régional de Mesures Physiques de l'Ouest. All experiments were performed in the dark.

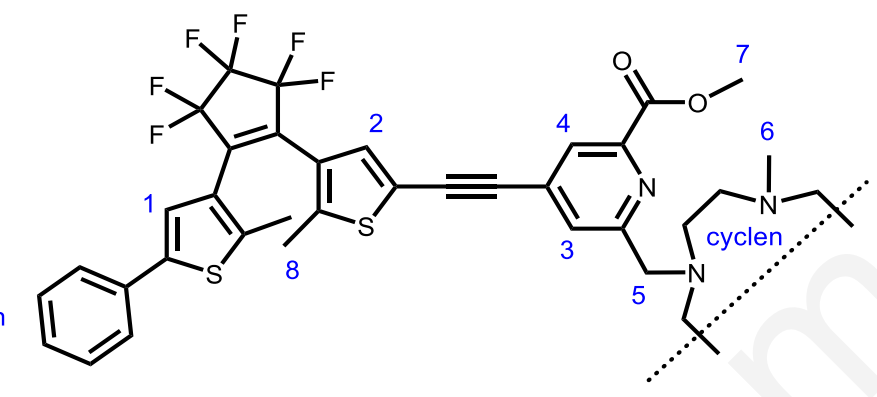

Scheme 3. Numbering used for NMR assignment.

Compound 3. A solution of dimethyl-cyclen $(60 \mathrm{mg}, 0.3 \mathrm{mmol})$ and $\mathrm{K}_{2} \mathrm{CO}_{3}(165 \mathrm{mg}, 1.2 \mathrm{mmol}$, 4 eq) in $\mathrm{CH}_{3} \mathrm{CN}(7.5 \mathrm{~mL}$ ) was stirred at room temperature for $30 \mathrm{~min}$. To this solution was added dropwise a solution of compound 2 (447 mg, $0.63 \mathrm{mmol}, 2.1 \mathrm{eq})$ in $\mathrm{CH}_{3} \mathrm{CN}$ (11.4 mL). The reaction mixture was stirred at $60{ }^{\circ} \mathrm{C}$ for 2.5 days before evaporation of solvents to dryness. The residue was taken up in $\mathrm{CHCl}_{3}$ and the residual salts were filtered off. The filtrate was evaporated to dryness to give a brown oil which was dissolved in the minimum amount of ethyl acetate. A large amount of hexane was added and the formation of a dark precipitate was observed. The precipitate was filtered and the filtrate was evaporated and dried under vacuum to give compound 3 (410 $\mathrm{mg}$, $0.29 \mathrm{mmol}, 95 \%)$ as an orange oil. $\mathrm{Rf}\left(\mathrm{CH}_{2} \mathrm{Cl}_{2} / \mathrm{MeOH}\right.$, neutral alumina $)=0.25 .{ }^{1} \mathrm{H} \mathrm{NMR}(400$ $\left.\mathrm{MHz} \mathrm{CDCl}_{3}\right) \delta 8.48(\mathrm{~s}, 2 \mathrm{H}, \mathrm{H} 4), 7.96(\mathrm{~s}, 2 \mathrm{H}, \mathrm{H} 3), 7.53(\mathrm{~d}, J=7.6 \mathrm{~Hz}, 5 \mathrm{H}), 7.38(\mathrm{t}, J=7.6 \mathrm{~Hz}$, $265 \mathrm{H}), 7.30(\mathrm{~d}, J=7.2 \mathrm{~Hz}, 2 \mathrm{H}), 7.26(\mathrm{~s}, 2 \mathrm{H}), 3.95\left(\mathrm{~s}, 6 \mathrm{H}, \mathrm{H}_{7}\right), 3.87\left(\mathrm{~s}, 4 \mathrm{H}, \mathrm{H}_{5}\right), 2.66\left(\mathrm{br} \mathrm{s}, 8 \mathrm{H}, \mathrm{CH}_{2}\right.$ cyclen), 2.63 (brs, 8H, $\mathrm{CH}_{2}$ cyclen), 2.13 (s, 6H, 2* $\mathrm{H}_{6}$ ), 1.92 (s, 6H, 2* $\mathrm{H}_{8}$ ), 1.90 (s, 6H, 2* $\mathrm{H}_{8}$ ). 
${ }^{19} \mathrm{~F}$ NMR $\left(282 \mathrm{MHz}, \mathrm{CDCl}_{3}\right) \delta-107.52,-107.69,-129.29 .{ }^{13} \mathrm{C} \mathrm{NMR}\left(125 \mathrm{MHz}, \mathrm{CDCl}_{3}\right) \delta 165.4$

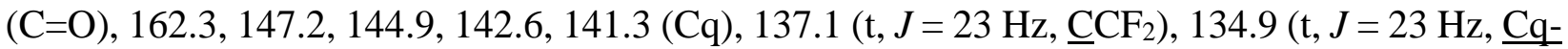

$\left.3 \quad \mathrm{CF}_{2}\right), 133.2(\mathrm{Cq}), 132.8,132.2(\mathrm{Cq}), 129.1,128.1,127.9,125.6(\mathrm{CH}), 125.5,125.4(\mathrm{Cq}), 124.7$, $122.1(\mathrm{CH}), 120.2(\mathrm{Cq}), 116.0\left(\mathrm{tt},{ }^{1} J_{\mathrm{C}-\mathrm{F}}=255 \mathrm{~Hz},{ }^{2} J_{\mathrm{C}-\mathrm{F}}=23 \mathrm{~Hz}\right.$, external $\left.\mathrm{CF}_{2}\right), 110.9$ (tquint, ${ }^{1} J_{\mathrm{C}-\mathrm{F}}$ $=270 \mathrm{~Hz},{ }^{2} J_{\mathrm{C}-\mathrm{F}}=25 \mathrm{~Hz}$, central $\left.\mathrm{CF}_{2}\right), 91.7,86.5$ (alkyne), $61.0\left(\mathrm{CH}_{2}\right.$-pico), 56.1, $53.9\left(\mathrm{CH}_{2}\right.$ cyclen),

$52.9\left(\mathrm{COOCH}_{3}\right), 44.3\left(\mathrm{CH}_{3}\right.$ cyclen), 14.54, $14.49\left(\mathrm{C}_{8}\right)$. ESI-HR-MS (positive, MeOH) $\mathrm{m} / z$ calcd. for $\left[\mathrm{C}_{72} \mathrm{H}_{63} \mathrm{~F}_{12} \mathrm{~N}_{6} \mathrm{O}_{4} \mathrm{~S}_{4}\right]^{+}:$1431.3597, found: $1431.3598,[\mathrm{M}+\mathrm{H}]^{+}$; calcd. for $\left[\mathrm{C}_{72} \mathrm{H}_{62} \mathrm{~F}_{12} \mathrm{~N}_{6} \mathrm{NaO}_{4} \mathrm{~S}_{4}\right]^{+}$: 1453.3416, found: 1453.3420, $[\mathrm{M}+\mathrm{Na}]^{+}$; calcd. for $\left[\mathrm{C}_{72} \mathrm{H}_{64} \mathrm{~F}_{12} \mathrm{~N}_{6} \mathrm{O}_{4} \mathrm{~S}_{4}\right]^{2+}$ : 716.1835 , found: $9716.1842,[\mathrm{M}+2 \mathrm{H}]^{2+}$.

Loo. A solution of compound $3(100 \mathrm{mg}, 69.8 \mu \mathrm{mol})$ and $\mathrm{KOH}(1 \mathrm{M}, 4.37 \mathrm{~mL})$ in THF $(8.73 \mathrm{~mL})$ was stirred at room temperature for $26 \mathrm{~h}$. Phases were separated and the aqueous phase was extracted with $\mathrm{CH}_{2} \mathrm{Cl}_{2}(2 \times 10 \mathrm{~mL})$. The combined organic phases were dried over $\mathrm{MgSO}_{4}$ and solvents were evaporated to dryness. The residue was dissolved in the minimum of ethyl acetate and a large amount of hexane was added. The precipitate was filtered and taken up in $\mathrm{CHCl}_{3}$ to give $\mathbf{L}_{\mathbf{o o}}(70 \mathrm{mg}, 47.3 \mu \mathrm{mol}, 68 \%)$ as an orange oil. ${ }^{1} \mathrm{H}$ NMR $\left(500 \mathrm{MHz}, \mathrm{CDCl}_{3}\right) \delta 7.84(\mathrm{~s}, 2 \mathrm{H})$, $7.52(\mathrm{~d}, J=7.5 \mathrm{~Hz}, 4 \mathrm{H}), 7.37(\mathrm{t}, J=7.5 \mathrm{~Hz}, 4 \mathrm{H}), 7.33(\mathrm{~s}, 2 \mathrm{H}), 7.31-7.23(\mathrm{~m}, 4 \mathrm{H}), 7.09(\mathrm{~s}, 2 \mathrm{H})$, $4.12-2.16$ (H of the cyclen), $1.94\left(\mathrm{~s}, 6 \mathrm{H}, 2 * \mathrm{H}_{8}\right), 1.92\left(\mathrm{~s}, 6 \mathrm{H}, 2 * \mathrm{H}_{8}\right), 1.81\left(\mathrm{~s}, 6 \mathrm{H}, 2 * \mathrm{H}_{6}\right) .{ }^{13} \mathrm{C} \mathrm{NMR}$ $\left(125 \mathrm{MHz}, \mathrm{CDCl}_{3}\right) \delta 170.3,157.3,144.4,142.6,141.4(\mathrm{Cq}), 137.0\left(\mathrm{t}, J=23 \mathrm{~Hz}, \underline{\mathrm{CCF}}_{2}\right), 135.2(\mathrm{t}$, $\left.J=23 \mathrm{~Hz}, \underline{\mathrm{CCF}}_{2}\right), 133.2(\mathrm{Cq}), 132.5(\mathrm{CH}), 131.1(\mathrm{Cq}), 129.1,128.0,125.6(\mathrm{CH}), 125.5,125.3$ $(\mathrm{Cq}), 125.1,124.5,122.2(\mathrm{CH}), 120.9(\mathrm{Cq}), 116.0\left(\mathrm{tt},{ }^{1} J_{\mathrm{C}-\mathrm{F}}=255 \mathrm{~Hz},{ }^{2} J_{\mathrm{C}-\mathrm{F}}=25 \mathrm{~Hz}\right.$, external $\left.\mathrm{CF}_{2}\right)$, 110.9 (tquint, ${ }^{1} J_{\mathrm{C}-\mathrm{F}}=270 \mathrm{~Hz},{ }^{2} J_{\mathrm{C}-\mathrm{F}}=25 \mathrm{~Hz}$, central $\left.\mathrm{CF}_{2}\right), 92.2,85.3$ (alkyne), $62.1\left(\mathrm{CH}_{2}\right.$ pico), 51.1 ( $\mathrm{CH}_{2}$ cyclen), 43.2 ( $\mathrm{CH}_{3}$ cyclen), $14.7\left(\mathrm{C}_{8}\right), 14.5\left(\mathrm{C}_{8}\right)$. ESI-HR-MS (positive, $\left.\mathrm{MeOH}\right) \mathrm{m} / z$ calcd. for $\left[\mathrm{C}_{70} \mathrm{H}_{59} \mathrm{~F}_{12} \mathrm{~N}_{6} \mathrm{O}_{4} \mathrm{~S}_{4}\right]^{+}: 1403.3284$, found: $1403.3296,[\mathrm{M}+\mathrm{H}]^{+}$; calcd. for $\left[\mathrm{C}_{70} \mathrm{H}_{60} \mathrm{~F}_{12} \mathrm{~N}_{6} \mathrm{O}_{4} \mathrm{~S}_{4}\right]^{2+}$ : 702.1678, found: 702.1688, $[\mathrm{M}+2 \mathrm{H}]^{2+}$ with $\mathrm{M}$ referring to the conjugated diacid of $\mathrm{L}_{\mathrm{oo}}$.

[YLoo]Cl. To a solution of compound Loo $(60 \mathrm{mg}, 41 \mu \mathrm{mol})$ in $\mathrm{MeOH}$ (HPLC grad, $10 \mathrm{~mL}$ ) was added $\mathrm{YCl}_{3} .6 \mathrm{H}_{2} \mathrm{O}(37 \mathrm{mg}, 122 \mu \mathrm{mol}, 3 \mathrm{eq})$. The $\mathrm{pH}$ was controlled at 7 and the reaction mixture was stirred at room temperature for 3.5 days. Solvents were evaporated to dryness and water was added to the residue. Water was then filtered on cotton and the solid kept on the cotton was dissolved with $\mathrm{CH}_{3} \mathrm{CN}$ (HPLC grad). $\mathrm{CH}_{3} \mathrm{CN}$ was evaporated to dryness and the residue was dissolved in the minimum of $\mathrm{CH}_{2} \mathrm{Cl}_{2}$. A large amount of hexane was added and the precipitated 
was filtered, washed with hexane and dried under vacuum to yield [YLoo]Cl $(38 \mathrm{mg}, 25 \mu \mathrm{mol}$, $61 \%$ ) as a pale yellow solid. ${ }^{1} \mathrm{H} \mathrm{NMR}\left(500 \mathrm{MHz}, \mathrm{CDCl}_{3}, 253 \mathrm{~K}\right) \delta: 8.10$ (s, 2H), 7.61 (s, 2H), 7.55 (d, $J=7.5 \mathrm{~Hz}, 4 \mathrm{H}), 7.46$ (s, 2H), 7.40 (t, $J=7.2 \mathrm{~Hz}, 4 \mathrm{H}), 7.32$ (d, J= $7.7 \mathrm{~Hz}, 2 \mathrm{H}), 7.29$ (s, 2H), $4.68(\mathrm{~d}, J=13.3 \mathrm{~Hz}, 4 \mathrm{H}), 4.49$ (br s, 2H), 4.05 (d, $J=15.2 \mathrm{~Hz}, 2 \mathrm{H}), 3.17$ (br s, 2H), 3.05 (d, $J=$ $10.7 \mathrm{~Hz}, 2 \mathrm{H}), 2.89$ (d, $J=11.8 \mathrm{~Hz}, 2 \mathrm{H}), 2.80$ (s, 2H), 2.70 (d, $J=10.5 \mathrm{~Hz}, 2 \mathrm{H}), 2.24-2.12(\mathrm{~m}$, 2H), $2.04\left(\mathrm{~s}, 6 \mathrm{H}, 2 * \mathrm{H}_{6}\right), 1.92\left(\mathrm{~s}, 6 \mathrm{H}, 2 * \mathrm{H}_{8}\right), 1.89$ (s, 6H, 2* $\left.\mathrm{H}_{8}\right) .{ }^{13} \mathrm{C} \mathrm{NMR}\left(125 \mathrm{MHz}, \mathrm{CDCl}_{3}\right) \delta$ $168.2(\mathrm{C}=\mathrm{O}), 152.6,146.5,142.7,141.3(\mathrm{Cq}), 137.6\left(\mathrm{~m}, \underline{\mathrm{Cq}-\mathrm{CF}_{2}}\right), 137.3(\mathrm{Cq}), 134.8\left(\mathrm{~m}, \underline{\mathrm{Cq}}-\mathrm{CF}_{2}\right)$, 134.4 (C2), 133.1 (Cq), 129.0, 128.1 , 125.9 (Ar), 125.8 (Cq), 125.6 (Ar), 125.3 (Cq), 122.0 (C1), $119.1(\mathrm{Cq}), 115.9\left(\mathrm{tt},{ }^{1} J_{\mathrm{C}-\mathrm{F}}=255 \mathrm{~Hz},{ }^{2} J_{\mathrm{C}-\mathrm{F}}=25 \mathrm{~Hz}\right.$, external $\left.\mathrm{CF}_{2}\right), 110.9$ (tquint, ${ }^{1} J_{\mathrm{C}-\mathrm{F}}=270 \mathrm{~Hz}$, ${ }^{2} J_{\mathrm{C}-\mathrm{F}}=25 \mathrm{~Hz}$, central $\left.\mathrm{CF}_{2}\right), 91.3,90.2$ (Cq alkyne), $54.2\left(\mathrm{CH}_{2}\right.$ cyclen $), 46.1\left(\mathrm{CH}_{3}\right.$ cyclen $), 14.64$ $\left(\mathrm{C}_{8}\right), 14.58\left(\mathrm{C}_{8}\right) .{ }^{19} \mathrm{~F}$ NMR $\left(376 \mathrm{MHz}, \mathrm{CDCl}_{3}\right) \delta-110.55,-110.78,-132.34 .{ }^{89} \mathrm{Y}$ NMR (HMBC $\left.{ }^{1} \mathrm{H} /{ }^{89} \mathrm{Y}, \mathrm{CDCl}_{3}\right) \delta$ 250.9. ESI-HR-MS (positive, $\left.\mathrm{MeOH}\right) \mathrm{m} / z$ calcd. for $\left[\mathrm{C}_{70} \mathrm{H}_{56} \mathrm{~F}_{12} \mathrm{~N}_{6} \mathrm{O}_{4} \mathrm{~S}_{4} \mathrm{Y}\right]^{+}$: 1489.2107, found: 1489.2114, $[\mathrm{M}+\mathrm{H}]^{+}$; calcd. for $\left[\mathrm{C}_{70} \mathrm{H}_{57} \mathrm{~F}_{12} \mathrm{~N}_{6} \mathrm{O}_{4} \mathrm{~S}_{4} \mathrm{Y}\right]^{2+}$ : 745.1090 , found: $745.1102,[\mathrm{M}+2 \mathrm{H}]^{2+}$.

[YbLoo]Cl. Compound Loo (60 mg, $0.041 \mathrm{mmol})$ was dissolved in $13 \mathrm{~mL}$ of methanol and $\mathrm{YbCl}_{3} .6 \mathrm{H}_{2} \mathrm{O}(24 \mathrm{mg}, 0.061 \mathrm{mmol})$ was then added. After stirring at room temperature for 3.5 days, the solvent was evaporated under vacuum. Water was added and the resulting suspension was filtered. The solid was then extracted with acetonitrile. After evaporation of the solvents, the crude solid was dissolved in the minimum amount of dichloromethane and precipitated in hexane yielding [Y $\mathbf{Y b L o o} \mathbf{C l}$ as a white bluish solid $(51 \mathrm{mg}, 80 \%) .{ }^{1} \mathrm{H} \mathrm{NMR}:\left(500 \mathrm{MHz}, \mathrm{CD}_{2} \mathrm{Cl}_{2}\right) \delta 83.88$ $\left(2 \mathrm{H}, \mathrm{H}_{3} / \mathrm{H}_{4}\right), 55.60\left(2 \mathrm{H}, \mathrm{H}_{3} / \mathrm{H}_{4}\right), 27.35$ (2H, $\left.\mathrm{H}_{\text {cyclen }}\right), 20.29\left(2 \mathrm{H}, \mathrm{H}_{\text {cyclen }}\right), 15.43\left(2 \mathrm{H}, \mathrm{H}_{\text {cyclen }}\right), 10.47$ $\left(2 \mathrm{H}, \mathrm{H}_{\text {cyclen }}\right), 7.35-7.22\left(10 \mathrm{H}, \mathrm{H}_{\mathrm{ph}}\right), 6.97\left(2 \mathrm{H}, \mathrm{H}_{2}\right), 6.37\left(2 \mathrm{H}, \mathrm{H}_{1}\right), 1.60-1.50\left(12 \mathrm{H}, \mathrm{CH}_{3}\right),-2.53(2 \mathrm{H}$, $\left.\mathrm{H}_{\text {cyclen }}\right),-7.12\left(2 \mathrm{H}, \mathrm{H}_{\text {cyclen }}\right),-15.92\left(2 \mathrm{H}, \mathrm{H}_{\text {cyclen }}\right),-30.94\left(6 \mathrm{H}, \mathrm{H}_{6}\right),-40.64\left(2 \mathrm{H}, \mathrm{H}_{\text {cyclen }}\right)$. EA C 49.07; $\mathrm{H}$ 3.78; $\mathrm{S} 6.52 ; \mathrm{N} 4.41$, Calcd for $\mathrm{C}_{70} \mathrm{H}_{56} \mathrm{ClF}_{12} \mathrm{~N}_{6} \mathrm{O}_{4} \mathrm{~S}_{4} \mathrm{Yb} .5 \mathrm{H}_{2} \mathrm{O} \mathrm{C} 49.46 ; \mathrm{H}$ 3.91; S 7.54; N 4.94 ESI-HR-MS (positive, MeOH) $m / z$ calcd. for $\left[\mathrm{C}_{70} \mathrm{H}_{56} \mathrm{YbF}_{12} \mathrm{~N}_{6} \mathrm{O}_{4} \mathrm{~S}_{4}\right]^{+}$: 1574.2456, found: 1574.2437, $[\mathrm{M}+\mathrm{H}]^{+}$; calcd. for $\left[\mathrm{C}_{70} \mathrm{H}_{57} \mathrm{YbF}_{12} \mathrm{~N}_{6} \mathrm{O}_{4} \mathrm{~S}_{4}\right]^{2+}:$ 787.6277, found: $787.6295,[\mathrm{M}+2 \mathrm{H}]^{2+}$.

[YbLcc]Cl was obtained upon UV irradiation (see SI). ${ }^{1} \mathrm{H}$ NMR $\left(500 \mathrm{MHz}, \mathrm{CD}_{2} \mathrm{Cl}_{2}\right) \delta 84.99(2 \mathrm{H}$, $\left.\mathrm{H}_{3} / \mathrm{H}_{4}\right), 53.37\left(2 \mathrm{H}, \mathrm{H}_{3} / \mathrm{H}_{4}\right), 27.44$ (2H, $\left.\mathrm{H}_{\text {cyclen }}\right), 21.74$ (2H, $\left.\mathrm{H}_{\text {cyclen }}\right), 14.92$ (2H, $\left.\mathrm{H}_{\text {cyclen }}\right), 11.24-9.50$ $\left(2 \mathrm{H}, \mathrm{H}_{\text {cyclen}}\right), 7.42-7.33\left(10 \mathrm{H}, \mathrm{H}_{\mathrm{ph}}\right), 6.51\left(2 \mathrm{H}, \mathrm{H}_{2}\right), 5.65\left(2 \mathrm{H}, \mathrm{H}_{1}\right), 1.76-1.70\left(12 \mathrm{H}, \mathrm{CH}_{3}\right),-2.24(2 \mathrm{H}$, $\left.\mathrm{H}_{\text {cyclen }}\right),-6.44\left(2 \mathrm{H}, \mathrm{H}_{\text {cyclen }}\right),-16.34\left(2 \mathrm{H}, \mathrm{H}_{\text {cyclen }}\right),-32.25\left(6 \mathrm{H}, \mathrm{H}_{6}\right),-38.40\left(2 \mathrm{H}, \mathrm{H}_{\text {cyclen }}\right)$. 
1 [EuL oo] Cl. Compound $\mathbf{L}_{\mathbf{o o}}$ (46 mg, $0.031 \mathrm{mmol}$ ) was dissolved in $10 \mathrm{~mL}$ of methanol (HPLC grad)

2 and $\mathrm{EuCl}_{3} \cdot 6 \mathrm{H}_{2} \mathrm{O}(28 \mathrm{mg}, 0.076 \mathrm{mmol})$ was then added. After stirring at room temperature for 3.5

3 days, the solvent was evaporated under vacuum. Water was added and the resulting suspension was

4 filtered. The solid was then extracted with acetonitrile (HPLC grad). After evaporation of the

5 solvents, the crude solid was dissolved in the minimum amount of dichloromethane and

6 precipitated in hexane yielding [EuLoo] Cl as a pale yellow solid (44 mg, $90 \%) .{ }^{1} \mathrm{H}$ NMR (500

$\left.7 \mathrm{MHz}, \mathrm{CD}_{2} \mathrm{Cl}_{2}\right) \delta 38.43\left(2 \mathrm{H}, \mathrm{H}_{3} / \mathrm{H}_{4}\right), 25.75\left(2 \mathrm{H}, \mathrm{H}_{3} / \mathrm{H}_{4}\right), 7.49\left(\mathrm{~d}, 4 \mathrm{H}, \mathrm{H}_{\mathrm{ph}}\right), 7.36\left(\mathrm{t}, 4 \mathrm{H}, \mathrm{H}_{\mathrm{ph}}\right), 7.28(\mathrm{t}$,

$\left.84 \mathrm{H}, \mathrm{H}_{\mathrm{ph}}\right), 7.20\left(2 \mathrm{H}, \mathrm{H}_{2}\right), 7.04\left(2 \mathrm{H}, \mathrm{H}_{1}\right), 2.59-2.34\left(10 \mathrm{H}, \mathrm{H}_{5}+6 \mathrm{H}_{\text {cyclen }}\right) 1.99\left(6 \mathrm{H}, 2 * \mathrm{H}_{8}\right), 1.85(6 \mathrm{H}$,

$\left.92 * \mathrm{H}_{8}\right),-3.09\left(2 \mathrm{H}, \mathrm{H}_{\text {cyclen }}\right),-7.56\left(2 \mathrm{H}, \mathrm{H}_{\text {cyclen }}\right),-9.13\left(6 \mathrm{H}, \mathrm{H}_{6}\right),-10.28\left(2 \mathrm{H}, \mathrm{H}_{\text {cyclen }}\right),-13.52(2 \mathrm{H}$,

$\left.10 \mathrm{H}_{\text {cyclen }}\right),-15.45\left(2 \mathrm{H}, \mathrm{H}_{\text {cyclen }}\right)$. EA C 50.94; $\mathrm{H} 3.81 ; \mathrm{S} 7.39 ; \mathrm{N} 4.76$, Calcd for $\mathrm{C}_{70} \mathrm{H}_{56} \mathrm{ClF}_{12} \mathrm{~N}_{6} \mathrm{O}_{4} \mathrm{~S}_{4} \mathrm{Eu} .4 \mathrm{H}_{2} \mathrm{O}$

$11 \mathrm{C} 50.62 ; \mathrm{H} 3.88$; $\mathrm{S} 7.72 ; \mathrm{N}$ 5.06. ESI-HR-MS (positive, $\mathrm{MeOH}$ ) $\mathrm{m} / z$ calcd. for $\left[\mathrm{C}_{70} \mathrm{H}_{56} \mathrm{EuF}_{12} \mathrm{~N}_{6} \mathrm{O}_{4} \mathrm{~S}_{4}\right]^{+}$:

12 1553.2261, found: 1553.2264, $[\mathrm{M}+\mathrm{H}]^{+}$; calcd. for $\left[\mathrm{C}_{70} \mathrm{H}_{57} \mathrm{EuF}_{12} \mathrm{~N}_{6} \mathrm{O}_{4} \mathrm{~S}_{4}\right]^{2+}$ : 777.1167, found:

$13777.1178,[\mathrm{M}+2 \mathrm{H}]^{2+}$.

14 [EuLcc]Cl was obtained upon UV irradiation (see SI), ${ }^{1} \mathrm{H}$ NMR $\left(500 \mathrm{MHz}, \mathrm{CD}_{2} \mathrm{Cl}_{2}\right) \delta 38.68(2 \mathrm{H}$, $\left.15 \mathrm{H}_{3} / \mathrm{H}_{4}\right), 24.96\left(2 \mathrm{H}, \mathrm{H}_{3} / \mathrm{H}_{4}\right), 7.55-7.43\left(10 \mathrm{H}, \mathrm{H}_{\mathrm{ph}}\right), 6.70\left(2 \mathrm{H}, \mathrm{H}_{2}\right), 6.20\left(2 \mathrm{H}, \mathrm{H}_{1}\right), 2.89\left(10 \mathrm{H}, \mathrm{H}_{5}+\right.$ $\left.166 \mathrm{H}_{\text {cyclen }}\right), 2.11-2.09\left(12 \mathrm{H}, \mathrm{CH}_{3}\right),-3.52\left(2 \mathrm{H}, \mathrm{H}_{\text {cyclen }}\right),-7.91\left(2 \mathrm{H}, \mathrm{H}_{\text {cyclen }}\right),-9.50\left(8 \mathrm{H}, 6 \mathrm{H}_{6}\right.$ and $\left.2 \mathrm{H}_{\text {cyclen }}\right)$, $17-13.79\left(2 \mathrm{H}, \mathrm{H}_{\text {cyclen }}\right),-15.11\left(2 \mathrm{H}, \mathrm{H}_{\text {cyclen }}\right)$. 


\section{References}

2 (1) Andreasson, J.; Pischel, U., Smart molecules at work-mimicking advanced logic operations. Chem.

3 Soc. Rev. 2010, 39 (1), 174-188.

4 (2) Browne, W. R.; Feringa, B. L., Light Switching of Molecules on Surfaces. In Annu. Rev. Phys. Chem., 5 2009; Vol. 60, pp 407-428.

6 (3) Heffern, M. C.; Matosziuk, L. M.; Meade, T. J., Lanthanide Probes for Bioresponsive Imaging. Chem.

7 Rev. 2014, $114(8), 4496-4539$.

8 (4) Tian, Z. Y.; Li, A. D. Q., Photoswitching-Enabled Novel Optical Imaging: Innovative Solutions for Real-

9 World Challenges in Fluorescence Detections. Acc. Chem. Res. 2013, 46 (2), 269-279. europium(III) complex for advanced anti-counterfeiting and encryption. Dalton Trans. 2016, 45 (13), 5451-5454.

(6) Qi, Q.; Li, C.; Liu, X.; Jiang, S.; Xu, Z.; Lee, R.; Zhu, M.; Xu, B.; Tian, W., Solid-State Photoinduced Luminescence Switch for Advanced Anticounterfeiting and Super-Resolution Imaging Applications. J. Am. Chem. Soc. 2017.

(7) Zhang, J. J.; Zou, Q.; Tian, H., Photochromic Materials: More Than Meets The Eye. Adv. Mater. 2013, 25 (3), 378-399.

(8) Zhou, W.; Chen, Y.; Yu, Q.; Li, P.; Chen, X.; Liu, Y., Photo-responsive cyclodextrin/anthracene/Eu3+ supramolecular assembly for a tunable photochromic multicolor cell label and fluorescent ink. Chem. Sci. 2019, 10 (11), 3346-3352.

(9) Yuasa, J.; Nakagawa, T.; Kita, Y.; Kaito, A.; Kawai, T., Photoactivatable europium luminescence turnon by photo-oxygenation of $\beta$-diketone having pyrrole rings. Chem. Commun. 2017, 53 (50), 6748-6751. (10) Nakagawa, T.; Hasegawa, Y.; Kawai, T., Photoresponsive europium(III) complex based on photochromic reaction. J. Phys. Chem. A 2008, 112 (23), 5096-5103.

(11) Nakagawa, T.; Atsumi, K.; Nakashima, T.; Hasegawa, Y.; Kawai, T., Reversible luminescence modulation in photochromic europium(III) complex having triangle terthiazole ligands. Chem. Lett. 2007, 36 (3), 372-373.

(12) Koji, M.; Yoshio, N.; Keiichi, K., Photochemical Modulation of Europium Ion Fluorescence Using a Tetraazamacrocyclic Derivative Bearing a Spirobenzopyran and Three Carboxymethyl Moieties. Bull. Chem. Soc. Jpn. 2009, 82 (4), 472-474.

(13) Hasegawa, Y.; Nakagawa, T.; Kawai, T., Recent progress of luminescent metal complexes with photochromic units. Coord. Chem. Rev. 2010, 254 (21-22), 2643-2651.

(14) Cheng, H. B.; Hu, G. F.; Zhang, Z. H.; Gao, L.; Gao, X.; Wu, H. C., Photocontrolled Reversible Luminescent Lanthanide Molecular Switch Based on a Diarylethene-Europium Dyad. Inorg. Chem. 2016, 55 (16), 7962-8.

(15) Wang, N.; Wang, J.; Zhao, D.; Mellerup, S. K.; Peng, T.; Wang, H.; Wang, S., Lanthanide Complexes with Photochromic Organoboron Ligand: Synthesis and Luminescence Study. Inorg. Chem. 2018, 57 (16), 10040-10049.

(16) Cheng, H.-B.; Zhang, H.-Y.; Liu, Y., Dual-Stimulus Luminescent Lanthanide Molecular Switch Based on an Unsymmetrical Diarylperfluorocyclopentene. J. Am. Chem. Soc. 2013, 135 (28), 10190-10193.

(17) Irie, M.; Fulcaminato, T.; Matsuda, K.; Kobatake, S., Photochromism of Diarylethene Molecules and Crystals: Memories, Switches, and Actuators. Chem. Rev. 2014, 114 (24), 12174-12277.

(18) He, X.; Norel, L.; Hervault, Y.-M.; Métivier, R.; D’Aléo, A.; Maury, O.; Rigaut, S., Modulation of Eu(III) and $\mathrm{Yb}$ (III) Luminescence Using a DTE Photochromic Ligand. Inorg. Chem. 2016, 55 (24), 12635-12643.

(19) Bui, A. T.; Beyler, M.; Liao, Y.-Y.; Grichine, A.; Duperray, A.; Mulatier, J.-C.; Guennic, B. L.; Andraud, C.; Maury, O.; Tripier, R., Cationic Two-Photon Lanthanide Bioprobes Able to Accumulate in Live Cells. Inorg. Chem. 2016, 55 (14), 7020-7025. 
(20) Bui, A. T.; Beyler, M.; Grichine, A.; Duperray, A.; Mulatier, J.-C.; Guyot, Y.; Andraud, C.; Tripier, R.; Brasselet, S.; Maury, O., Near infrared two photon imaging using a bright cationic $\mathrm{Yb}$ (iii) bioprobe spontaneously internalized into live cells. Chem. Commun. 2017, 53 (44), 6005-6008.

(21) Stasiuk, G. J.; Long, N. J., The ubiquitous DOTA and its derivatives: the impact of 1,4,7,10tetraazacyclododecane-1,4,7,10-tetraacetic acid on biomedical imaging. Chem. Commun. 2013, 49 (27), 2732-2746.

(22) Clough, T. J.; Jiang, L.; Wong, K.-L.; Long, N. J., Ligand design strategies to increase stability of gadolinium-based magnetic resonance imaging contrast agents. Nat. Commun. 2019, 10 (1), 1420.

(23) Moore, E. G.; Samuel, A. P. S.; Raymond, K. N., From Antenna to Assay: Lessons Learned in Lanthanide Luminescence. Acc. Chem. Res. 2009, 42 (4), 542-552.

(24) Shuvaev, S.; Starck, M.; Parker, D., Responsive, Water-Soluble Europium(III) Luminescent Probes. Chem. Eur. J. 2017, 23 (42), 9974-9989.

(25) Rodríguez-Rodríguez, A.; Garda, Z.; Ruscsák, E.; Esteban-Gómez, D.; de Blas, A.; Rodríguez-Blas, T.; Lima, L. M. P.; Beyler, M.; Tripier, R.; Tircsó, G.; Platas-Iglesias, C., Stable Mn2+, Cu2+ and Ln3+ complexes with cyclen-based ligands functionalized with picolinate pendant arms. Dalton Trans. 2015, 44 (11), 5017-5031.

(26) Rodríguez-Rodríguez, A.; Esteban-Gómez, D.; de Blas, A.; Rodríguez-Blas, T.; Fekete, M.; Botta, M.; Tripier, R.; Platas-Iglesias, C., Lanthanide(III) Complexes with Ligands Derived from a Cyclen Framework Containing Pyridinecarboxylate Pendants. The Effect of Steric Hindrance on the Hydration Number. Inorg. Chem. 2012, 51 (4), 2509-2521.

(27) Al Sabea, H.; Norel, L.; Galangau, O.; Hijazi, H.; Metivier, R.; Roisnel, T.; Maury, O.; Bucher, C.; Riobe, F.; Rigaut, S., Dual Light and Redox Control of NIR Luminescence with Complementary Photochromic and Organometallic Antennae. J. Am. Chem. Soc. 2019, 141 (51), 20026-20030.

(28) Bourdolle, A.; Allali, M.; Mulatier, J.-C.; Le Guennic, B.; Zwier, J. M.; Baldeck, P. L.; Buenzli, J.-C. G.; Andraud, C.; Lamarque, L.; Maury, O., Modulating the Photophysical Properties of Azamacrocyclic Europium Complexes with Charge-Transfer Antenna Chromophores. Inorg. Chem. 2011, 50 (11), 49874999.

(29) Xing, Y.; Jindal, A. K.; Regueiro-Figueroa, M.; Le Fur, M.; Kervarec, N.; Zhao, P.; Kovacs, Z.; Valencia, L.; Pérez-Lourido, P.; Tripier, R.; Esteban-Gómez, D.; Platas-Iglesias, C.; Sherry, A. D., The Relationship between NMR Chemical Shifts of Thermally Polarized and Hyperpolarized 89Y Complexes and Their Solution Structures. Chem. Eur. J. 2016, 22 (46), 16657-16667.

(30) Pintacuda, G.; John, M.; Su, X.-C.; Otting, G., NMR structure determination of protein-ligand complexes by lanthanide labeling. Acc. Chem. Res. 2007, 40 (3), 206-212.

(31) Fihey, A.; Perrier, A.; Browne, W. R.; Jacquemin, D., Multiphotochromic molecular systems. Chem. Soc. Rev. 2015, 44 (11), 3719-3759.

(32) Nakagawa, T.; Hasegawa, Y.; Kawai, T., Nondestructive luminescence intensity readout of a photochromic lanthanide(III) complex. Chem. Commun. 2009, (37), 5630-5632.

(33) Al Sabea, H.; Norel, L.; Galangau, O.; Roisnel, T.; Maury, O.; Riobé, F.; Rigaut, S., Efficient photomodulation of visible $\mathrm{Eu}(\mathrm{III})$ and invisible $\mathrm{Yb}$ (III) luminescences using DTE photochromic ligands for optical encryption Adv. Funct. Mater. 2020, 2002943 